\title{
AS PERSPECTIVAS \\ CONTEMPORÂNEAS ACERCA \\ DO PRINCÍPIO DA AUTODETERMINAÇÃO \\ DOS POVOS
}

\section{Thalita Carneiro Ary}

Mestra em Relações Internacionais (UnB)

Professora de Direito Internacional Público da FA7

thalitary@gmail.com

Sumário: Introdução. 1) Princípio da autodeterminação dos povos.

2) O princípio da autodeterminação dos povos e os atuais problemas africanos. Conclusão.

Resumo: O princípio da autodeterminação dos povos inicia sua trajetória para se consolidar como um princípio do Direito Internacional Público a partir da criação das Nações Unidas, em 1945. Após a incorporação do citado princípio em sua Carta, a Assembléia Geral da ONU passa a proferir inúmeras resoluções as quais corroboraram para moldar um direito consuetudinário referente à autodeterminação dos povos. Convergindo para o real fortalecimento deste princípio, o fenômeno histórico da descolonização dos países africanos, ocorrido em meados dos anos 50 e 60, teve uma enorme relevância, uma vez que os clamores por libertação desses povos colocaram o tema em destaque. No entanto, após o término do processo descolonizador, emerge a indagação acerca do desmembramento desse princípio além do caráter meramente anti-colonial, estendendo sua aplicabilidade também para os movimentos separatistas no interior de Estados soberanos. Surge, dessa maneira, a possibilidade de legitimação da chamada autodeterminação interna, alentando os desígnios de povos que desejem a secessão da entidade estatal soberana a qual estão submetidos.

Palavras-chave: Autodeterminação dos Povos. Nações Unidas. África.

\section{INTRODUÇÃO}

O presente artigo visa o estudo e a análise do princípio do Direito Internacional referente à autodeterminação dos povos. Nesse contexto, analisa-se a importância do processo de descolonização africana para a efetiva consolidação da autodeterminação dos povos como um princípio de Direito Internacional Público. Também não poderá ser olvidado o estudo da atual situação africana, concernente à possibilidade de aplicação do referido princípio para a consecução dos intentos de secessão no continente africano. 
Em fins do século XIX, um fenômeno eivado por anseios imperialistas das grandes potências européias assola a África, ocasionando a partilha de praticamente todo o continente africano de maneira vil, e rebaixando-o à condição de colônia européia. Essa situação de subjugação perdurou por, aproximadamente, setenta anos, quando, em meados dos anos cinqüenta, iniciou uma incrível proliferação de movimentos nacionalistas de independência, os quais libertam o continente das amarras coloniais. Vale ressaltar que o continente asiático também foi dividido entre os europeus, embora de maneira menos predatória que na África.

A descolonização africana ocorreu de maneira mais efetiva durante a década de sessenta, uma vez que a maioria da África Subsaariana obteve a independência. O processo de libertação é apenas arrematado no ano de 1975, com a independência das colônias portuguesas de Angola e Moçambique, findando, dessa maneira, o longo período de dominação européia na África. É nesse contexto histórico que surge a discussão acerca da autodeterminação dos povos, direito este que vem sendo invocado desde os remotos tempos da Declaração de Independência dos Estados Unidos, embora apenas tenha iniciado seu percurso para se tornar um princípio consolidado do Direito Internacional em virtude desse período descolonizador.

No entanto, deve-se aclarar a razão da escolha do caso africano para explicar o surgimento, no contexto internacional, do princípio da autodeterminação dos povos. O fato é que a colonização asiática ocorreu de maneira mais amena, tendo em vista que os europeus dividiram certos países por áreas de influência, muitos deles sob a forma de protetorados. Excetuando o traumático caso da dominação francesa, na região da Indochina, a conquista da Ásia mostrou-se menos incisiva que a africana, não necessitando, em seu processo de descolonização, invocar de forma veemente o direito de os povos se autodeterminarem.

Destarte, os constantes clamores por autodeterminação proferidos pelos africanos foram decisivos para que as Nações Unidas, por meio de inúmeras resoluções, houvesse reconhecido e proclamado efetivamente o princípio da autodeterminação dos povos. O mesmo passou por inúmeros processos de evolução no contexto da ONU, até possuir seu definitivo delineamento como um direito de todos os povos serem livres, possuindo a prerrogativa de se autodeterminarem de forma independente e incompatível com investidas colonialistas. Saliente-se que a autodeterminação dos povos foi incorporada na Constituição Brasileira de 1988, fazendo parte do rol de princípios pelos quais o Brasil se rege em suas Relações Internacionais. Contudo, o principal aspecto referente a este princípio é a possibilidade de, além de proteger a luta contra a colonização, também possa legitimar a ocorrência de movimentos de secessão em Estados soberanos consolidados.

Nessa ótica, analisa-se a possibilidade de o princípio da autodeterminação dos povos também abrigar tais movimentos separatistas em sua aura de legitimação, 
possibilitando a autodeterminação de minorias étnicas que vivem sob a égide de Estados que não condizem com sua real configuração cultural e racial.

\section{PrincíPio da AutodeterminaÇão dos POVOS}

Especificar o exato momento em que surge a idéia do princípio de os povos se autodeterminarem é bastante complicada de realizar, tendo em vista que inúmeros fatores históricos uniram-se para consagrar o referido princípio na forma em que hoje se apresenta. Assim sendo, pode-se contextualizar seus antecedentes nos tempos das Revoluções americana e francesa, ambas no final do século XVIII, as quais trouxeram à tona o expresso consentimento pelos princípios da liberdade, igualdade, soberania e independência dos povos.

Também não se pode deixar de mencionar a relevância dos nacionalismos do século XIX, no contexto da evolução do princípio da autodeterminação dos povos. Com o aparecimento do Estado-Nação Westfaliano, surge a concepção de que cada entidade estatal deve possuir um território determinado, um governo soberano, o qual não dependa de nenhuma outra entidade estatal, exercendo sua soberania relativamente a uma população determinada. Entretanto, alguns juristas tradicionais apontam o elemento povo, que está mais ligado à noção de nação ${ }^{1}$, como um dos componentes básicos desse Estado Nacional, ao invés do elemento população. Magnoli (1997, p. 15) ressalta essa idéia ao afirmar:

A nação ergueu-se sobre a consciência da unidade cultural e do destino de um povo, expressa nos símbolos da pátria e apoiada na distinção entre o natural e o estrangeiro. Apenas o Estado-Nação associou definitivamente os conceitos de povo e nação ao território, estabelecendo os vínculos de natureza abstrata - ou seja: ideológica - entre eles.

A partir de meados da Primeira Guerra Mundial, pela primeira vez, o princípio da autodeterminação dos povos aparece como um importante elemento no cenário internacional. Surge com duas versões, uma radical e a outra mais moderada. A primeira é defendida por Lênin (apud FALK, 2000, p. 104) em meio ao processo da Revolução Russa, consubstanciando-o como imprescindível para a paz mundial e referindo-se, mais precisamente, aos povos não-europeus que se

\footnotetext{
1 Apresenta-se extremamente complicado atribuir um conceito absoluto de nação, tendo em vista ser uma noção bastante subjetiva. No entanto, esboça-se como idéia geral de nação uma coletividade unida por laços de cultura, tradições, línguas e etnia comum, apresentando caráter de solidariedade entre seus membros para a manutenção da unidade do grupo. Também cabe considerar que, irrefutavelmente, a mesma não se confunde com o Estado, uma vez que este apresenta conceito eminentemente jurídico, enquanto que a nação apresenta um aspecto sociológico.
} 
encontravam em condição de dominação. Este afirmava: "The liberation of all colonies, the liberation of all dependent, oppressed, and nonsovereign people is necessary for the maintenance of international peace."

Muitos autores consideram o ideário leninista como um dos marcos intelectuais para o desenvolvimento do princípio, salientando Morais (1998, p. 142 e 143) que:

Entende a doutrina que a idéia de autodeterminação dos povos bebeu em termos filosóficos, num primeiro momento, na Declaração de Independência dos Estados Unidos e no pensamento jeffersoniano que se lhe encontrara subjacente e num segundo, no pensamento leninista, essencialmente emancipalista e anti-imperialista.

A versão moderada da defesa do princípio da autodeterminação dos povos, elaborada pelo presidente norte-americano Woodrow Wilson, foi a escolhida para que o citado princípio iniciasse seu caminho até se tornar um corolário do Direito Internacional.

Wilson pretendia impor o imediato alcance do princípio aos povos da Europa que se encontravam subjugados tanto ao Império Otomano, quanto ao Império Austro-Húngaro. Também estendia sua atuação aos povos coloniais não-europeus, embora de forma mais cautelosa e ambígua. Enquanto que Lênin pregava a autodeterminação de todos os povos, Wilson restringiu sua aplicação apenas dentro dos parâmetros coloniais, sem desejar a dissolução da referida ordem, ou seja, estendia a autodeterminação aos povos "civilizados". Receava, assim, que uma ampliação do alcance do princípio pudesse causar instabilidade nessa nova ordem, pela proliferação de movimentos de secessão.

Contudo, a maneira mais ampla e idealista, preconizada por Lênin, foi, sem dúvida, a maior fonte de inspiração dos movimentos nacionalistas que viriam a proliferar no pós-Segunda Guerra Mundial. Já a ideologia mais limitada de Wilson em seus Quatorze Pontos, fez com que o princípio da autodeterminação dos povos iniciasse sua trajetória para se tornar um preceito consolidado do Direito Internacional Público, o que viria a ocorrer após a criação das Nações Unidas.

\subsection{As NaÇões Unidas e a CONSOldidÇão do PRINCíPIO}

Com o fim da Segunda Guerra Mundial e a conseqüente criação da Organização das Nações Unidas (ONU), em 1945, inicia-se uma nova fase para o princípio da autodeterminação dos povos, começando, assim, sua caminhada para se consagrar como um princípio do Direito Internacional Público.

Durante o período de incorporação de um tex to que se referisse ao direito dos povos se autodeterminarem, no escopo da Carta da ONU, assistiu-se a 
volta do embate entre as visões leninista e wilsoniana. A concepção de Lênin consagrava esta idéia como um "direito" inerente aos povos, estendendo-a aos que estavam com amarras coloniais. A posição da União Soviética (URSS) baseou-se nessa ideologia leninista ao apoiar a dialética de que a ordem colonial deveria ser questionada.

Por outro lado, as enfraquecidas potências européias advogavam pela não interferência em seus assuntos coloniais, predestinadas a mantê-las pela força, caso necessário. Os Estados Unidos procuram adotar uma posição menos incisiva já que tinham os europeus como aliados estratégicos, embora carregasse o legado de luta pelos ideais libertários e de independência. Portanto, o suporte jurídico do princípio da autodeterminação dos povos está contido nos artigos 1 e 55 da Carta da ONU.

Cabe atentar ao fato de o texto considerar a autodeterminação como um princípio e não um direito, atestando certa incoerência normativa no trato da questão. Falk (2000, p. 106) corrobora para esse entendimento ao explicitar: to the extent that a principle exists and is actualized, it implies the existence of rights and duties to ensure its application, or at least encompasses the prospect that such rights will, as appropriate, be specified and realized.

Somente em decorrência da influência dos clamores e movimentos de independência dos povos coloniais, a ONU passa a consagrar, em seus subseqüentes textos, que os povos possuem o "direito" de se autodeterminarem. Desse modo, entende Orentlicher (2000, p. 1256) que: "[....] previously associated with the right of subject nationalities to form their own state, to metamorphose into a right of colonial territories to break free of the metropolitan state."

Vale salientar que o referido princípio foi ainda reforçado ao ser incorporado no texto de duas convenções internacionais, quais sejam: o Pacto de Direitos Civis e Políticos e o Pacto de Direitos Econômicos e Sociais, ambos de 1966, os quais representaram um grande avanço haja vista que possuem caráter de obrigatoriedade aos Estados signatários, colaborando para consolidação do princípio na esfera internacional.

Portanto, os dispositivos acima mencionados são o suporte jurídico do princípio da autodeterminação dos povos, atestando que o mesmo não se trata de mera concepção política, já que se encontra expressamente disposto em importantes instrumentos jurídicos do Direito Internacional, ou seja, está amparado num direito fundamental do homem, que é o de se dispor autonomamente. Dessa forma, posiciona-se o citado direito no campo dos "Direitos Humanos", posto que seus titulares são os "povos", caracterizando-se como um direito coletivo, sem detrimento aos auspícios individuais. 


\subsection{A INCIDÊnCIA DA DESCOLONIZAÇÃo AFRICANA NA AUTO- DETERMINAÇÃO DOS POVOS}

Após a Segunda Guerra Mundial, ocorreram modificações, em inúmeros sentidos, sob a égide do Direito Internacional. E uma dessas mudanças aconteceu com o princípio da autodeterminação dos povos. Inicialmente surgido como um princípio, na Carta das Nações Unidas, serviu de inspiração ao surgimento dos movimentos emancipalistas de possessões ainda coloniais. Posteriormente, transformou-se no "direito" de os povos se autodeterminarem em virtude do processo de descolonização das colônias africanas e asiáticas, ocorrido em meados da década de 50 e durante os anos 60 .

Nesse contexto, a Assembléia Geral da ONU atuou, durante o período das independências africanas, de forma a moldar a estrutura do referido princípio mediante inúmeras resoluções. Neste período, havia uma perceptível discrepância de opiniões entre os países colonialistas europeus, de um lado, e o bloco dos independentes países asiáticos e africanos e do socialista, no tocante à qual interpretação deveria ser dada aos artigos primeiro e 55 da Carta.

Os países europeus com territórios coloniais desejavam caracterizar o princípio da autodeterminação dos povos de maneira mais programática e sem aplicação imediata, enquanto que os países terceiro-mundistas independentes, principalmente após a Conferência de Bandung ${ }^{2}$, passaram a vislumbrá-lo como um aliado na luta contra o colonialismo. Entretanto, a resoluções das Nações Unidas posicionaram-se claramente em favor dos clamores anti-coloniais, promovendo fervorosas discussões entre seus membros, divididos entre os favoráveis e desfavoráveis a esta visão.

Considera-se marcante a Resolução $\mathrm{n}^{\circ} 1514$, de 14 de dezembro de 1960, a qual ficara conhecida como "Declaração sobre a Concessão de Independência aos Países e Povos Coloniais". A referida Declaração condenou a existência de povos subjugados e explorados por outros países, atestando que fere os direitos dos homens e os dispositivos de sua Carta, além de obstaculizar a promoção da paz, segurança e cooperação internacional.

Com fins de assegurar a observância das recomendações contidas na Declaração para a descolonização, as Nações Unidas, por meio da Resolução 1654, de 1961, da Assembléia Geral, criou um comitê especial o qual ficara conhecido como "Comitê dos 24". Este tinha a incumbência de analisar a aplicação da Declaração, além de trabalhar para sua implementação. Dessa

\footnotetext{
2 A Conferência de Bandung ocorreu em 1955, na Ilha de Java, Indonésia, contando com a participação de vinte e nove países africanos e asiáticos. Tinha como objetivo precípuo uma nova inserção dos países descolonizados na atual dinâmica da Guerra Fria, advogando pela formação de um bloco eqüidistante das relações antagônicas entre leste capitalista e oeste socialista.
} 
forma, a "Declaração sobre a Concessão de Independência aos Países e Povos Coloniais" foi aclamada como essencial para a consolidação do princípio de os povos se disporem por si próprios, a partir daí também considerado um direito. Dessa forma, considera-se o período do pós-guerra mundial até os anos 70 como a segunda fase de afirmação do princípio da autodeterminação dos povos, conhecida pelo seu desdobramento descolonizador.

Portanto, percebe-se clara a constatação de que o processo de descolonização caracterizou-se como fundamental para a aceitação internacional do referido princípio, além de lançar suas características basilares. Vale ainda ressaltar que o inverso também ocorreu, haja vista que o trabalho desempenhado pela ONU para, inicialmente, reconhecer o princípio e, posteriormente, o direito de os povos se autodeterminarem, influenciou e incentivou o fenomenal processo de independência dos países africanos nos anos 60 .

Mostra-se incontestável o fato de que ambos os processos possuíram uma ingente conexão, já que quase todos os países africanos e asiáticos tornaramse independentes, enquanto que o princípio da autodeterminação dos povos emergiu no cenário internacional com força de princípio do Direito Internacional Público. Não esquecendo de ressaltar que essas resoluções acerca do princípio da autodeterminação dos povos criaram, indubitavelmente, um direito costumeiro da descolonização, inserido na categoria de costume internacional.

\subsection{Apenas UM diReito de DESCOLONIZAÇÃo?}

O princípio da autodeterminação dos povos, por seu caráter consuetudinário, adquiriu suas peculiaridades ao longo da trajetória para se firmar como um instrumento do Direito Internacional. Dessa forma, acabou apresentando uma abrangência ramificada e repleta de indagações, como se vê na seqüência. Mostra-se imensamente complicado traçar um perfil único da autodeterminação dos povos, tendo em vista os inúmeros desdobramentos que a questão apresenta. Sob a égide do Direito Internacional, o direito de os povos se autodeterminarem refere-se a dois pontos: um deles se assenta no art. $1^{\circ}$ dos Pactos de 1966 e exprime que a autodeterminação é essencial para a efetiva proteção aos direitos humanos; enquanto que o outro desdobramento caracteriza o direito de grupos étnicos possuírem o efetivo controle da sua coletividade de indivíduos de forma soberana. O primeiro traz uma idéia abstrata a qual o incorpora na égide dos Direitos Humanos, sendo na segunda assertiva que paira o ponto sensível da questão.

Então se indaga: este direito de autodeterminação dos povos refere-se, numa visão limitada, apenas aos territórios que possuem fronteiras delimitadas e se encontram dominados por outro país, ou também abrange os clamores de grupos étnicos os quais lutam pela secessão de territórios já delimitados? 
Primeiramente, percebe-se que o titular para o exercício do princípio da autodeterminação dos povos sofreu modificações em razão de mutações sofridas na ordem política, jurídica e ideológica internacional. A primeira abordagem das Nações Unidas relacionada à questão da autodeterminação, tanto nos dispositivos de sua Carta, quanto nos constantes dos Pactos de 1966 e na Declaração sobre a Concessão de Independência aos Países e Povos Coloniais, mostrou uma abrangência limitada aos auspícios da descolonização.

Falk (2000, p. 108) assinala que a abordagem da Declaração de 1960 é objetiva no propósito de relacionar o princípio da autodeterminação dos povos com as questões anti-coloniais, renegando uma aplicação mais abrangente. Isto se deve em virtude do receio de que ocorressem distúrbios na integridade territorial de Estados soberanos, advindos de movimentos separatistas de grupos étnicos no interior destes, caso uma visão mais ampla fosse atribuída ao citado princípio.

Nesse contexto, Orentlicher $(2000$, p. 1254) relata que não apenas os Estados já estabelecidos estavam engajados na tarefa de estreitar a aplicação da autodeterminação dos povos apenas no sentido de findar o colonialismo, como também os novos Estados africanos independentes. A preocupação maior se dava pelo temor da proliferação de movimentos de secessão pelos inúmeros grupos tribais, os quais habitavam o interior das fronteiras dos recém-formados países africanos. Higgins (apud FALK, 2000, p. 109) concorda com essa visão ao afirmar que se não existir estabilidade das fronteiras, a autodeterminação dos povos torna-se sem utilidade.

A Organização da Unidade Africana aderiu ao princípio da autodeterminação dos povos, o do uti possidetis, ou seja, os territórios dependentes teriam como fronteiras aquelas traçadas no período colonial ${ }^{3}$. Queria, assim, evitar que a independência e a estabilidade desses novos países fossem violadas. Este princípio também fora consagrado pelas Nações Unidas na Declaração de 1960, considerando que qualquer passo visando a quebra da unidade territorial de um país iria de encontro com os fins de sua Carta.

Falk (2000, p.99) considera esta visão irremediavelmente arbitrária, haja vista que priva a autodeterminação de povos que se encontrem sofrendo discriminações de raça, crença, cor e que não possam se determinar por si mesmos em seu próprio país, como o caso das minorias étnicas. Entretanto, as Nações Unidas, por meio da Resolução no 2625, de 1970, da Assembléia Geral, proclamaram a "Declaração Relativa aos Princípios do Direito Internacional Regendo as Relações Amistosas

\footnotetext{
Este princípio foi cunhado no século XIX, ao ser invocado nas independências das colônias espanholas na América Latina, estatuindo que devessem ser mantidas as antigas fronteiras estabelecidas antes da independência. O mesmo também foi utilizado no processo de descolonização da África, com o intuito de evitar a proliferação de movimentos separatistas, que causassem distúrbios na unidade territorial desses novos países.
} 
e Cooperação entre os Estados Conforme a Carta da ONU", a qual corrobora com o entendimento de que o princípio da autodeterminação dos povos não se aplicaria aos povos sob a égide de um Estado soberano.

Com relação à abordagem do princípio da autodeterminação dos povos na Declaração de 1970, este foi proclamado um princípio de Direito Internacional e não apenas um simples conceito moral. Atestara que os Estados deveriam se abster de impedir a emancipação, enquanto que os povos e movimentos de independência deveriam contar com todo o suporte e apoio da ONU, mediante o respeito a seus objetivos. No tocante à abrangência do princípio, a citada Declaração veio a confirmar a posição da ONU no sentido de limitar a autodeterminação dos povos a situações de luta contra a colonização. Trindade (2002, p. 126) explicita a questão:

[....] tentou traçar uma distinção entre os casos típicos de autodeterminação (no contexto imediatamente colonial) e os de secessão: em relação a estes últimos, resguardados os direitos das minorias, prevaleceu o entendimento de que não se deveria interpretar o princípio da autodeterminação de modo a abranger igual e amplamente os movimentos de secessão de grupos tribais, étnicos e religiosos (dentro de um país já independente).

Entretanto, uma terceira fase da retórica da autodeterminação dos povos emerge de acontecimentos históricos na década de 1990, provocados pelos nacionalismos pós-modernos. Dessa forma, o desmantelamento do bloco soviético, assim como da Yugoslávia, ocasionaram o aparecimento de diversos novos Estados oriundos de entes estatais já independentes e soberanos. Nesse contexto, o princípio da autodeterminação dos povos passou a ser invocado dentro de Estados soberanos por muito tempo já consolidados.

Destarte, Falk (2000, p.100) apresenta uma interessante fragmentação das vertentes que moldaram o principio da autodeterminação dos povos durante sua trajetória histórica. Primeiramente, referiu-se à batalha dos povos subjugados contra a dominação externa, visando a independência política dentro dos parâmetros de aceitação da esfera internacional.

Uma segunda vertente caracteriza a luta por independência de povos configurados dentro de um Estado estabelecido e soberano, como o caso de "Estados" ou "repúblicas" dentro de um sistema federado. Citam-se os exemplos da busca pela autodeterminação e autonomia, assim como a luta pela preservação de sua identidade cultural e proteção contra discriminações, realizadas pelas repúblicas pertencentes à União Soviética e Yugoslávia. O terceiro desmembramento referese a Estados unitários ou membros de uma unidade federada, como, por exemplo, Kosovo e Chechenia. Este caso é claro ao estabelecer a impossibilidade de contestar as fronteiras do Estado Federal, mas apenas uma extensão geográfica caracterizada como unidade administrativa de uma federação. 
Cabe apenas ressaltar que o Direito Internacional não atribui às nações ou minorias étnicas, que se encontram estabelecidas dentro de Estados com fronteiras delimitadas, a abrangência do princípio da autodeterminação dos povos. Logicamente, a ordem internacional atendera os apelos dos Estados soberanos, os quais estavam temerosos com a explosão de movimentos de secessão dentro de seus territórios e desestabilização da ordem.

\section{O PRINCÍPIO DA AUTODETERMINAÇÃO DOS POVOS E OS ATUAIS PROBLEMAS AFRICANOS}

Neste último tópico, aborda-se o atual problema vivido pelos países africanos no tocante aos inúmeros conflitos étnicos ocorridos no século $\mathrm{XX}$ e que continuam a pontilhar sua realidade.

\subsection{Fronteiras inCONGRUentes}

A África, antes da colonização, organizava-se por meio de uma infinidade de tribos e clãs distintos, sem existência de fronteiras rigidamente estabelecidas e sem grandes compatibilidades entre eles, haja vista que possuíam peculiaridades culturais e étnicas específicas e distintas entre si. Na realidade, a noção de fronteira referia-se à condição de vassalagem a um suserano ao qual estava subordinado, modificando esta fronteira à medida que não mais devia obediência aquele chefe. Assim sendo, viviam numa organização social bastante rudimentar, ou seja, numa realidade jurídica pré-estatal.

Esta configuração foi totalmente modificada com o advento da partilha do continente pelos europeus, já que as fronteiras dos novos Estados africanos foram construídas de acordo com os auspícios dos interesses políticos e econômicos dos colonizadores. Destaque-se que o aspecto referente à heterogeneidade étnica, cultural e tribal africana não foi levado em consideração para a nova formação cartográfica do continente, traçando os limites mediante aspectos geográficos e geométricos.

Dessa maneira, os novos Estados africanos abrigavam uma enorme quantidade de grupos multi-étnicos e multi-tribais, não possuindo vínculos culturais entre si e constituindo um fator de enfraquecimento da autoridade central. Magnoli (2004, p. 324) corrobora para o citado entendimento salientando que: "os europeus inventaram territórios que não tinham raízes nas experiência históricas africanas. Os Estados africanos independentes, que surgiram no pós-guerra, herdaram as linhas de limites traçadas pelas potências européias".

É por esse aspecto que se afigura difícil tratar os Estados africanos como nações e, nesse sentido, aplicar o princípio das nacionalidades, posto que os 
mesmos são considerados "nações em desenvolvimento". Morais (1998, p. 272) explicita essa questão afirmando que: "O Estado precedeu aqui a nação, corporizou a função de aglutinar uma multiplicidade de comunidades humanas diversas, numa comunidade maior, dotada dos rudimentos de uma consciência comum".

Vale salientar que a Organização da União Africana (OUA) colaborou para a formação desses Estados instáveis e sem autenticidade, haja vista que adotara o princípio do uti possidetis juris para a delimitação das fronteiras africanas, mantendo inalterada a incongruente cartografia do período colonial e sem demonstrar preocupações com os reajustamentos étnicos necessários para o continente. Nessa mesma ótica, Tsiranana, presidente de Madagascar, apóia a atitude da OUA ao afirmar (apud MORAIS, 1998, p. 275): "Não é possível modificar as fronteiras das nações em nome de critérios raciais e religiosos [....] dado que, com efeito, se nós tomarmos por critério de fronteira, a raça, a tribo e a religião, haverá em África países que desaparecerão do mapa”. Entretanto, a indagação pertinente a esta situação é qual a razão de, após tantas árduas lutas pela independência, os líderes desta "nova" África preferirem a manutenção da configuração limítrofe do período colonial, sem colocar em pauta os aspectos inerentes à realidade da multiplicidade tribal do continente. Magnoli (2004, p. 329 e 330) apresenta duas respostas para a referida pergunta, atestando que:

A resposta cínica, mas em parte verdadeira, para essa questão, é que os líderes africanos representavam elites étnicas cujo poder estava assentado justamente nos Estados existentes, que, portanto, deviam ser conservados. A questão admite, porém, outra resposta, que é também parcialmente verdadeira. A África não tinha "fronteiras africanas" disponíveis para substituir aquelas criadas pelas potências européias.

O problema é que, mesmo antes da colonização européia, praticamente não existiam Estados consolidados no continente africano, não havendo como resgatar uma configuração de fronteiras a qual não existia. Por outro lado, um fator crucial também corroborou para a manutenção das fronteiras coloniais: o medo de que uma onda de movimentos separatistas viesse à tona, em virtude da heterogeneidade étnica desses recentes Estados. A OUA entendeu que movimentos internos de secessão seriam um risco para a integridade territorial dos países, assim como para sua própria existência como Estados. Nesse sentido, mostrou-se patente o entendimento da referida organização da diferenciação entre a autodeterminação dos povos e a secessão, pontilhando que a primeira se refere apenas à luta anticolonial, enquanto que a segunda se apresenta totalmente rechaçada de sua Carta e das futuras resoluções que seriam proferidas pela OUA.

A instabilidade interna, após a formação dos Estados africanos, era inevitável, haja vista que existia uma enormidade de povos culturalmente incongruentes vivendo no mesmo território, sob a errônea idéia de pertencerem a uma nação. 
Assim, inúmeros conflitos étnicos marcaram a realidade africana desde a metade do século XX até os dias de hoje.

O fato é que, após finda a Guerra Fria, os governos ditatoriais africanos não mais recebiam financiamento das superpotências visando o alinhamento automático a um dos lados, tornando-os incapazes de esmagar revoltas separatistas que se proliferavam intensamente. Destarte, após anos sufocados, os conflitos étnicos e guerras civis vieram à tona na década de 90 , atingindo, principalmente, os países da África Subsaariana. Citam-se casos como os conflitos tribais e clânicos na Libéria e Somália; a intensa diversidade étnica que geram distúrbios em Serra Leoa, Congo, Níger, Nigéria e Quênia até os dias de hoje; a guerra multi-étnica na Etiópia (conflito com a Eritréia); além do genocídio ocorrido contra os povos tutsis, em Ruanda, no ano de 1994, numa matança que gerou mais de um milhão de mortos. Vale ainda ressaltar que um genocídio também de grandes proporções vem ocorrendo em Darfur, no Sudão.

Dessa forma, a herança das incompatíveis fronteiras demarcadas pelos europeus na época da colonização, além da consolidação de um direito costumeiro regional africano, o qual rejeitava veementemente as tentativas separatistas e desconsiderava a autodeterminação dos povos para tais casos, foram as principais causas incentivadoras dessa ebulição étnica no continente.

\subsection{RECONHECIMENTO DO "DIREITO À SECESSÃO"}

Os contemporâneos problemas africanos levam a argumentar se o princípio da autodeterminação adentrou num estágio de legitimar um "direito à secessão", concebido na égide do Direito Internacional Público. Mostra-se relevante indagar qual o papel do referido princípio no contexto dos movimentos separatistas africanos, analisando sua adaptação a esta nova realidade e contextualizando-o com os anseios de territórios desse continente que, até os dias de hoje, buscam constituir-se como Estados soberanos, como a Somalilândia, Ogaden, Biafra e Cabinda e Saara Ocidental.

A ONU não legitima nem encoraja movimentos separatistas no interior de Estados já consolidados soberanamente, embora não proíba expressamente ações de independências em certas situações distintas. Desse modo, não se posiciona totalmente favorável à manutenção da integridade territorial de Estados soberanos que desrespeitem o principio da autodeterminação dos povos, ou oprimam seus povos com medidas de discriminação por razão de raça, religião e cor, violando, dessa forma, o princípio da igualdade entre os povos. Morais (1998, p. 258) salienta: "Não existe, por conseguinte, uma carta branca outorgada aos Estados para petrificarem situações de injustiça e desigualdade que, em violação manifesta do Direito Internacional, redundem em abuso do direito à integridade territorial". Por esta razão, certos doutrinadores consubstanciam o princípio da integridade territorial com certa relativização. 
Entretanto, apesar de não proibir expressamente a ocorrência de movimentos separatistas, a ONU sempre se mostrou ingentemente negligente com relação às violações de direitos das minorias que mostrassem anseios de secessão. Interveio apenas em casos de patente genocídio, o qual lançasse perigo de ameaçar fronteiras vizinhas. A atitude desse organismo internacional foi retratada nas palavras de Boutros Boutros Ghali, Secretário Geral da ONU, no período de 1992 a 1996, atestando a posição da organização em não exortar movimentos separatistas: "If every ethnic, religious or linguistic group claimed statehood, there would be no limit to fragmentation, and peace, security and economic well-being for all would become even more difficult to achieve."

Destarte, a ONU não aceita nenhum tipo de secessão violenta, uma vez que a considera um ilícito internacional. No entanto, a denegação em aceitar esse tipo de segregação de um Estado soberano não impede que, por meio de acordos entre as partes envolvidas, ocorra a independência de certos territórios alojados no interior de Estados soberanamente constituídos. No momento em que o direito interno dos Estados permita ou quando seus órgãos representativos decidam, a ONU reconhece esses Estados remanescentes de atos de secessão.

Esse tipo de segregação amigável é unanimemente aceito pela comunidade internacional, pois mesmo que o direito à secessão não seja reconhecido pelo Direito Internacional, não se impede a ocorrência de uma situação voluntariamente resolvida entre os interessados. Morais (1998, p. 262) explicita: “A secessão pacífica, legitimada tanto constitucionalmente pelo Direito interno dos Estados, como por acordos celebrados entre as autoridades representativas de parcelas territoriais da mesma realidade estadual, é sempre susceptível de aceitação". Tendo em vista a enfática posição das Nações Unidas e da sociedade internacional em não exortar e admitir casos de secessão dentro de Estados soberanos, pergunta-se o que ocorreu com a grande expectativa gerada pelo fenômeno da "autodeterminação interna", considerado a vertente contemporânea do princípio da autodeterminação dos povos.

Por qual razão os novos Estados advindos dos desmembramentos tanto da ex-URSS e da ex-Yugoslávia foram reconhecidos pela comunidade internacional como sujeitos ativos de um direito de autodeterminação dos povos, enquanto que posteriormente, principalmente nos casos africanos, o mesmo foi renegado?

A resposta mostra o caráter eminentemente efêmero dessa nova configuração da autodeterminação dos povos, uma vez que legitimou apenas casos isolados de independências, não se alastrando como uma prática aceita internacionalmente. Com relação à desfragmentação da ex-URSS em inúmeras

\footnotetext{
${ }^{4}$ Report of the Secretary-General - ONU. Doc. A/47/277 - S/24111 - 17 June 1992: An Agenda for Peace; Preventive diplomacy, peacemaking and peace-keeping.

5 Refere-se ao direito de um povo, parte de um Estado soberano, de definir livremente seu destino político.
} 
novas entidades estatais soberanas, invocaram-se a Constituição soviética de 1977 e o "Acordo e Minsk de 1991", já que ambos previam o direito de secessão de suas repúblicas. Alegou-se, para a situação dos Bálcãs, o fato da iminente ruptura da paz internacional ocasionada pela guerra da Bósnia, com casos de genocídio e conflitos étnicos, criando uma aura de legitimidade para o reconhecimento desses novos Estados desmembrados.

Essas explicações foram apresentadas ulteriormente, em decorrência do medo de que Estados inviáveis viessem a surgir na Europa oriental e em outras localidades, baseando-se nos exemplos de autodeterminação dos povos anteriormente citados. Atesta-se que a declaração unilateral de independência da República da Chechênia comprovou o temor da comunidade internacional na proliferação desses movimentos separatistas, ao quais iam de encontro aos anseios dos Estados soberanos. A partir daí, a esperança de que minorias étnicas viessem a invocar a autodeterminação dos povos para constituírem-se como entidades independentes e soberanas foi definitivamente sufocada pela ordem internacional. A única exceção no continente africano foi o reconhecimento da Eritréia, em 1993, como um Estado independente.

Assim sendo, a expectativa de que o princípio da autodeterminação dos povos fosse estendido ao intento separatista de muitos grupos étnicos, principalmente no continente africano, e que foi ilusionado com o surgimento de uma nova vertente do princípio, após 1989, acabara por ruir. A prevista onda separatista não se concretizou e a ONU continuou atribuindo à autodeterminação dos povos a mesma caracterização de antes, ao impedir sua correlação com o direito de secessão.

\section{Conclusão}

Demonstrou-se irrefutável, ao longo do presente artigo, a extrema interligação entre o evento referente ao processo da descolonização africana com a efetiva consolidação do princípio da autodeterminação dos povos. Os clamores por libertação e independência provenientes dos povos africanos criaram uma aura de aceitação internacional para legitimar e codificar o referido princípio, incluindo-o, por conseguinte, no rol de princípios do Direito Internacional Público.

No entanto, atualmente se fala de um novo desmembramento do princípio da autodeterminação dos povos, vindo, este, a perder o caráter iminentemente descolonizador. Pontilhou-se a necessidade de que pudesse abranger movimentos separatistas baseados na incompatibilidade étnica e cultural de povos submetidos a um Estado soberano consolidado, uma vez que os mesmos possuem o direito de se autodeterminarem, de acordo com seus anseios peculiares. As inúmeras guerras civis africanas, cunhadas no caráter de heterogeneidade de povos num mesmo Estado, criaram a perspectiva de legitimar movimentos de secessão com base no princípio da autodeterminação dos povos, visando consertar o erro cometido com a manutenção das fronteiras do período colonial. 
Por outro lado, o surgimento de novos Estados soberanos advindos da desfragmentação, tanto da ex-URSS quanto da ex-Yugoslávia, veio a corroborar com a idéia de uma nova vertente à autodeterminação dos povos, a qual seria estendida a casos particulares de secessões, que exprimissem a vontade de autodeterminação de povos oprimidos e desrespeitados pela entidade estatal soberana a qual fazem parte. Contudo, tanto as Nações Unidas quanto a OUA deslegitimaram esse desmembramento do referido princípio, ao reafirmarem a necessidade de respeito ao princípio do uti possidetis, declarando que nenhum Estado soberano poderá ter suas fronteiras modificadas a menos que concorde com tal desmembramento territorial.

Os casos da antiga URSS e Yugoslávia foram tratados como acontecimentos excepcionalmente considerados, alegando a comunidade internacional que o primeiro resultara de convenção livre e pacífica pelas entidades federadas, enquanto que o segundo legitimou-se pela deplorável situação de violência advinda da Guerra da Bósnia. Assim sendo, o impulso que o movimento da "autodeterminação interna" dos povos recebeu a partir de 1989 não se configurou no reconhecimento de uma situação libertária em favor de parcelas territoriais de Estados soberanos, haja vista que a comunidade internacional mostrou que qualquer ato de secessão violenta em Estados não coloniais são incompatíveis com o direito à autodeterminação dos povos.

Dessa maneira, conclui-se que o princípio da autodeterminação dos povos teve sua abrangência limitada apenas à situação de lutas coloniais, ao passo que lhe renegaram a possibilidade de libertação do ingente número de minorias étnicas sujeitas, na maioria das vezes, a segregações raciais ou religiosas, além de desrespeito a seus Direitos Humanos pelo país ao qual estão submetidas. A preocupação da Comunidade Internacional com a afronta à soberania de Estados nacionais territorialmente consolidados falou mais alto, relegando esse princípio ao escopo de nações que lutem contra a não mais existente, nos dias atuais, condição de colônia.

\section{REFERÊNCIAS}

\section{Fontes primárias:}

RESOLUÇÃO 334 da Assembléia Geral das Nações Unidas. Official Document System of the United Nation (ODS). Disponível em: <http://www.un.org/ documents/ga/res/4/ares4.htm>. Acesso em: 13 ago. 2007.

RESOLUÇÃO 743 da Assembléia Geral das Nações Unidas. Official Document System of the United Nation (ODS). Disponível em: <http://www.un.org/ documents/ga/res/8/ares8.htm>. Acesso em: 20 ago. 2007.

RESOLUÇÃO 1514 da Assembléia Geral das Nações Unidas. Official Document System of the United Nation (ODS). Disponível em: <http://www.un.org/ documents/ga/res/15/ares15.htm >. Acesso em: 20 ago. 2007. 
RESOLUÇÃO 1654 da Assembléia Geral das Nações Unidas. Official Document System of the United Nation (ODS). Disponível em: <http://www.un.org/ documents/ga/res/16/ares16.htm>. Acesso em: 20 ago. 2007.

RESOLUÇÃO 2625 da Assembléia Geral das Nações Unidas. Official Document System of the United Nation (ODS). Disponível em: <http://www.un.org/ documents/ga/res/25/ares25.htm>. Acesso em: 26 ago. 2007.

Livros:

BERMAN, Nathaniel. But the alternative is despair: european nationalism and the modernist renewal of international law. In: STEINER, Henry J.; ALSTON, Philip (org.). International human rights in context: law, politics, morals: text and materials. New York: Oxford University, 2000.

BRUNSCHWIG, Henri. A Partilha da África Negra. São Paulo: Perspectiva, 1974. BURITY, Tarcísio M. O Direito Internacional Consuetudinário e os Direitos Humanos. In: Os rumos do Direito Internacional dos Direitos Humanos. Ensaios em homenagem ao Professor Antônio Augusto Cançado Trindade. Porto Alegre: Sérgio Antonio Fabris, 2005.

CANEDO, Letícia Bicalho. A descolonização da Ásia e da África. São Paulo: Atual, 2005.

CERVO, Amado Luiz. Hegemonia coletiva e equilíbrio: a construção do mundo liberal (1815-1871). In: SARAIVA, José Flavio Sombra (org.). Relações internacionais: dois séculos de história. Entre a preponderância européia e a emergência americano-soviética (1815 - 1947). Brasília: FUNAG, 2001. v. 1.

. A instabilidade internacional (1919-1939). In: SARAIVA, José Flavio Sombra (org.). Relações internacionais: dois séculos de história. Entre a preponderância européia e a emergência americano-soviética (1815 - 1947). Brasília: FUNAG, 2001. v. 1.

DE MORAES, Alexandre. Direito Constitucional. 16. ed. São Paulo: Atlas, 2004.

. Direitos humanos fundamentais. Teoria Geral. São Paulo: Atlas, 2003. DE MORAIS, Carlos Blanco. O direito à autodeterminação dos povos. Estatuto jurídico do enclave de Cabinda. Lisboa: Universidade de Lisboa, 1998.

DOPCKE, Wolfgang. Apogeu e colapso do sistema internacional europeu (18711918). ). In: SARAIVA, José Flavio Sombra (org.). Relações internacionais: dois séculos de história. Entre a preponderância européia e a emergência americanosoviética (1815 - 1947). Brasília: FUNAG, 2001. v. 1.

FALK, Richard. Human Rights Horizons: The pursuit of justice in a globalizing world. New York: Routledge, 2000.

HOBSBAWM, Eric. Era dos extremos: o breve século XX. São Paulo: Companhia das Letras, 2004. 
HOBSBAWM, Eric. Era dos impérios. São Paulo: Companhia das Letras, 1989. KISSINGER, Henry. Diplomacia. Rio de Janeiro: Francisco Alves, 2000.

KOSKENNIEMI, Martti. National self-determination today: problems of legal theory and practice. In: STEINER, Henry J.; ALSTON, Philip (org.). International human rights in context: law, politics, morals: text and materials. New York: Oxford University, 2000.

MACHADO, Jónatas E. M. Direito Internacional. Do paradigma clássico ao pós-11 de Setembro. Coimbra: Coimbra, 2003.

MAGNOLI, Demétrio. Relações Internacionais: teoria e história. São Paulo: Saraiva, 2004.

. O corpo da pátria. Imaginação geográfica e política externa no Brasil (1808-1912). São Paulo: Unesp, 1997.

NATIONS, United. Basic facts: About the United Nations. New York: United Nations publication, 2000.

ORENTLICHER, Diane. External self-determination: some history, commentary and disputes. In: STEINER, Henry J.; ALSTON, Philip (org.). International human rights in context: law, politics, morals: text and materials. New York: Oxford University, 2000.

PIERRÉ-CAPS, Stéphane. O direito das minorias. ROULAND, Norbert (org.). Direito das minorias e dos povos autóctones. Brasília: UNB, 2004.

PIOSESAN, Flávia. Direitos Humanos e o Direito Constitucional Internacional. Rio de Janeiro: Saraiva, 1997.

POLÍTICOS, Pactos de direitos civis e. In: MAZZUOLI, Valério (org.). Coletânea de Direito Internacional. São Paulo: Revista dos Tribunais, 2004.

REZEK, J. F. Direito Internacional Público. Curso elementar. São Paulo: Saraiva, 2002. RODRIGUES, José Honório. Brasil e África: outro horizonte. Rio de Janeiro: Civilização Brasileira, 1964.

SARAIVA, José Flavio Sombra. Dois gigantes e um condomínio: da Guerra Fria à coexistência pacífica (1947-1968). In: Relações internacionais: dois séculos de história. Entre a ordem bipolar e o policentrismo (1947 a nossos dias). Brasília: FUNAG, 2001. v.2.

SILVA, José Afonso da. Curso de Direito Constitucional Positivo. São Paulo: Malheiros, 2001.

TRINDADE, Antônio Augusto Cançado. Direito Internacional em um mundo em transformação. Rio de Janeiro e São Paulo: Renovar, 2002.

. Princípios do Direito Internacional contemporâneo. Brasília: UNB, 1981. 
. Direito das organizações internacionais. Brasília: escopo, 1990.

UNIDAS, Carta das Nações. In: MAZZUOLI, Valério (org.). Coletânea de Direito Internacional. São Paulo: Revista dos Tribunais, 2004.

WESSELING, H. L. Dividir para dominar. A partilha da África (1880 - 1914). Rio de Janeiro: UFRJ, 1998.

\title{
Periódicos:
}

PINHEIRO, Letícia. Brasil, Portugal e descolonização africana (1946-60). Revista

Contexto Internacional, Rio de Janeiro, v. 4, n. 9, p. 91-109, Jan./Jun. 1989.

\section{CONTEMPORARY PERSPECTIVES ABOUT THE PRINCIPLE OF SELF-DETERMINATION OF PEOPLES}

\begin{abstract}
The principle of self-determination of peoples started its path to consolidate as a principle of the Public International Law at the moment the United Nations was created, in 1945. After the UN incorporated this principle into its charter, the General Assembly of the referred organization began to utter a considerable number of resolutions, corroborating to shape a customary law regarding the self-determination of peoples. Converging to the real strengthening of this principle, the historical phenomenon of the African decolonization, which took place in the decades of 1950 and 60, had an enormous relevance, so the liberation speech of those peoples was essential to put the issue into the sphere of the international community. However, by the time all African countries were free, the discussion about the fragmentation of this principle beyond the aspect merely non-colonial was provoked, also extending its applicability for the purposes of separatist motions inside sovereign states. Therefore, the possibility of legitimating the internal self-determination came out, animating the purposes of people that seek liberation from a sovereign state.
\end{abstract}

Keywords: Self-determination of peoples. United Nations. Africa. 